\title{
MACROZOOBENTHOS COMMUNITY STRUCTURE IN INTERTIDAL ZONE OF SAMBUNGO VILLAGE PESISIR SELATAN REGENCY OF WEST SUMATERA PROVINCE
}

\author{
Bob Anggara ${ }^{1}$, Afrizal Tanjung ${ }^{1}$, Syafruddin Nasution $^{1}$ \\ ${ }^{1}$ Department of Marine Science, Faculty of Fisheries and Marine Universitas Riau, Pekanbaru \\ *bobanggara09@gmail.com
}

\begin{abstract}
This research was conducted in the village of Sambungo, Silaut District, Pesisir Selatan Regency, West Sumatra Province in August 2020. The purpose of this study was to determine the structure of the macrozoobenthos community which includes: type, density, diversity, uniformity, dominance and distribution patterns. Sampling was done randomly at 3 stations, each station consists of 3 transects and each transect consists of 3 plots, namely in the upper middle and lower in the intertidal zone. The results of the study found 5 classes of macrozoobenthos with 9 species. The abundance values obtained ranged from $3.33-5.11$ $\mathrm{ind} / \mathrm{m}^{2}$. The diversity index value ranges from 1.18-1.54 which is classified as moderate, while the dominance index value ranges from $0.39-0.52$, namely there was no species that dominate, the uniformity index value ranges from 0.03-0.06 which is not balanced and the value of the distribution pattern ranges from 2.81 to 3.76 with the pattern of distribution in groups.
\end{abstract}

Keywords: Structure, Macrozoobentos, Intertidal Zone, and Sambungo Village

\section{PENDAHULUAN}

Zona intertidal adalah daerah pantai yang terletak antara pasang tinggi dan surut terendah, daerah ini mewakili peralihan dari kondisi lautan ke kondisi daratan. Semakin landai pantainya maka zona intertidalnya semakin luas, sebaliknya semakin terjal pantainya maka zona intertidalnya akan semakin sempit. Zona intertidal mengalami fluktuasi yang ekstrim terhadap faktor lingkungan ini disebabkan oleh perubahan komponen fisika dan kimia. Salah satu biota yang terdapat pada zona intertidal adalah makrozoobentos, dimana keberadaannya sangat penting dalam menjaga keseimbangan ekologi wilayah pesisir.

Makrozoobentos merupakan organisme yang hidupnya relatif menetap dan memiliki daya adaptasi yang bervariasi terhadap kondisi lingkungan. Makrozo- obentos dapat bersifat toleran maupun bersifat sensitif terhadap perubahan lingkungan. Secara ekologis makrozoobentos memiliki peran penting dalam rantai makanan. Mengingat bahwa perairan pesisir merupakan daerah yang rentan terhadap perubahan faktor lingkungan, baik dari berbagai kegiatan manusia maupun dari alam itu sendiri, maka perubahanperubahan ini dinilai akan memberi pengaruh bagi struktur komunitas makrozoobentos dalam jangka waktu yang panjang.

\section{METODE PENELITIAN Waktu dan Tempat}

Penelitian ini dilaksanakan pada bulan Agustus 2020 di Desa Sambungo Kecamatan Silaut Kabupaten Pesisir Selatan Provinsi Sumatera Barat. 


\section{Metode Penelitian}

Metode yang digunakan pada penelitian ini adalah metode survei. Sampel yang diperoleh dianalisis di Laboratorium Biologi Laut Fakultas Perikanan dan Kelautan Universitas Riau.

\section{Prosedur Penelitian}

Penentuan Titik Sampling

Penempatan stasiun dilakukan dengan dari 3 (tiga) stasiun berdasarkan kriteria, yaitu stasiun I berada jauh dari permukiman penduduk, stasiun II berada di wilayah wisata Pantai Sambungo dan stasiun III berada di dekat muara Sungai Sambungo. Masing - masing stasiun menggunakan 3 transek dan tiap transek terdiri dari 3 zona yaitu, lower zone, middle zone dan upper zone (Gambar 1).

Teknik purposive sampling yang terdiri

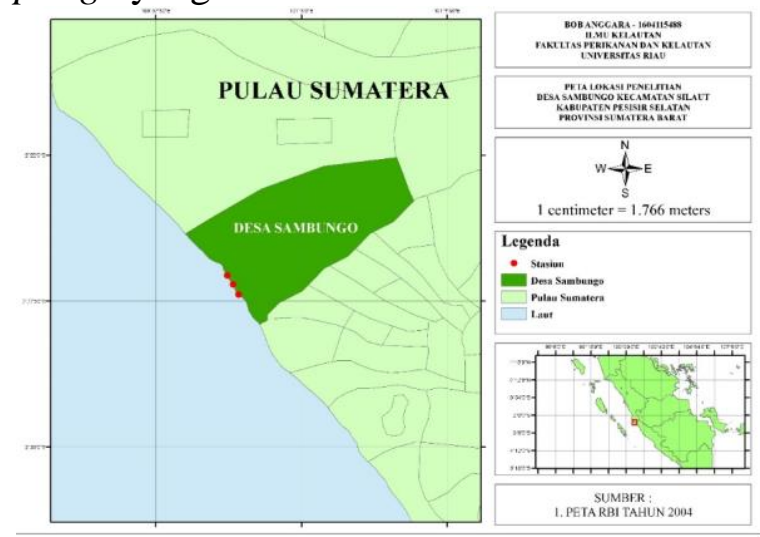

Gambar 1. Peta Lokasi Penelitian

\section{Analisis Kandungan Bahan Organik}

Prosedur analisis kandungan bahan organik pada sedimen dilakukan dengan menggunakan metode Loss on Ignition [1] dan Prosedur analisis struktur komunitas makrozoobentos menggunakan rumus [23].

\section{Pengukuran Kualitas Air}

Pengukuran parameter kualitas air terdiri dari derajat keasaman $(\mathrm{pH})$, suhu, kecerahan, dan salinitas.

\section{HASIL DAN PEMBAHASAN}

Kondisi Umum Lokasi Penelitian

Desa Sambungo merupakan daerah penelitian yang berlokasi di Kecamatan Silaut Kabupaten Pesisir Selatan Provinsi
Sumatera Barat dengan luas wilayah 1.996,41 Ha dengan jumlah penduduk sebanyak 1261 jiwa. Letak geografis Desa Sambungo berada pada $02^{\circ} 25^{\prime} 30,2^{\prime \prime}$ LS dan $101^{\circ} 01^{\prime} 36,0$ " BT. Di sekitar Pantai Sambungo terdapat pemukiman penduduk, jarak dari rumah penduduk dengan pantai tidak terlalu jauh. Namun daerah pesisir Desa Sambungo di dominasi oleh tanaman kelapa sawit milik masyarakat setempat.

\section{Parameter Lingkungan Perairan}

Hasil pengukuran kualitas air di zona intertidal Desa Sambungo didapat nilai suhu $28-29^{\circ} \mathrm{C}, \mathrm{pH}$ perairan 7 , sedangkan salinitas pada setiap stasiun penelitian berkisar antara 30-31\%. Hasil pengukuran kualitas air dapat dilihat pada Tabel 1

Tabel 1. Parameter Lingkungan Perairan di zona intertidal Desa Sambungo

\begin{tabular}{ccccc}
\hline Stasiun & $\mathbf{p H}$ & Suhu $\left({ }^{\mathbf{O}} \mathbf{C}\right)$ & Salinitas $(\mathbf{\% o})$ & Kecerahan $(\mathbf{c m})$ \\
\hline I & 7 & 28 & 30 & 25 \\
II & 7 & 29 & 31 & 25 \\
III & 7 & 29 & 31 & 20 \\
\hline
\end{tabular}




\section{Tipe Sedimen dan Bahan Organik}

Berdasarkan hasil analisis, di dapatkan bahwa tipe sedimen pada masing-masing stasiun ialah pasir. Persentase fraksi sedimen pasir tertinggi yaitu $96,53 \%$ pada lower zone Stasiun II dan yang terendah $81,07 \%$ pada middle zone Stasiun II. Perhitungan masingmasing tipe sedimen dapat dilihat pada Tabel 2.
Kandungan bahan organik berkisar antara 5,3-6,65\%. Kandungan bahan organic tertinggi terdapat pada Stasiun I zona Lower dengan jumlah persentase $6,65 \%$ sedangkan kandungan bahan organik yang terendah berada pada Stasiun II zona Lower dengan jumlah persentase $5,3 \%$. Perhitungan masing-masing kandungan bahan organik dapat dilihat pada Tabel 3

Tabel 2. Hasil Analisis Tipe Sedimen

\begin{tabular}{cccccc}
\hline Stasiun & Zona & Kerikil (\%) & Pasir (\%) & Lumpur (\%) & Tipe Sedimen \\
\hline \multirow{4}{*}{ I } & Lower & 0,02 & 87,78 & 12,20 & Pasir \\
& Middle & 0,05 & 86,26 & 13,69 & Pasir \\
& Upper & 2,02 & 93,85 & 4,14 & Pasir \\
& Lower & 0,27 & 96,53 & 3,20 & Pasir \\
II & Middle & 0,09 & 81,07 & 18,85 & Pasir \\
& Upper & 0,14 & 87,02 & 12,85 & Pasir \\
& Lower & 0,10 & 92,78 & 7,11 & Pasir \\
III & Middle & 0,04 & 87,15 & 12,81 & Pasir \\
& Upper & 0,03 & 94,18 & 5,79 & Pasir
\end{tabular}

Tabel 3. Kandungan Bahan Organik (\%)

\begin{tabular}{cccc}
\hline \multirow{2}{*}{ Zona } & \multicolumn{3}{c}{ Stasiun } \\
\cline { 2 - 4 } & I & II & III \\
\hline Lower & 7,74 & 6,22 & 7,26 \\
Middle & 6,49 & 4,51 & 5,59 \\
Upper & 5,72 & 5,17 & 6,01 \\
\hline Rata-rata & 6,65 & 5,3 & 6,29 \\
\hline
\end{tabular}

\section{Jenis Makrozoobenthos di Zona Intertidal Desa Sambungo}

Jenis Makrozoobentos yang didapatkan berdasarkan zona, pada zona lower didapatkan 3 spesies makrzoobenthos yang berbeda dari setiap stasiun, diantaranya ialah Nephtys sp., Sipunculus sp. dan A. carabus sedangkan pada zona Middle didapatkan 5 spesies makrzoobenthos, diantaranya ialah $E$. inca, A. striata, D. faba, O. stayelr dan T. terebra dan pada zona Upper didapatkan 4 spesies makrozoobentos, diantaranya ialah E. inca, A. striata, D. faba dan O.cordimanus. Jenis Makrozoobentos dapat dilihat pada Tabel 4.

Kepadatan makrozoobentos antar stasiun di zona intertidal Desa Sambungo tergolong rendah berkisar antara 3,33 -
$5,11 \mathrm{ind} / \mathrm{m}^{2}$. Rata-rata kepadatan makrozoobentos yang tertinggi terdapat pada Stasiun I dengan jumlah $5,11 \mathrm{ind} / \mathrm{m}^{2}$ sedangkan yang terendah terdapat pada Stasiun III dengan jumlah $3,33 \mathrm{ind} / \mathrm{m}^{2}$. Perbedaan kepadatan pada masing-masing stasiun dapat dilihat pada Gambar 2.

Kepadatan makrozoobentos didefinisikan sebagai jumlah individu yang terdapat di dalam sedimen per satuan luas, biasanya dalam satuan meter kuadrat atau sentimeter kuadrat. Dari hasil penelitian didapatkan kepadatan makrozoobentos tertinggi terdapat pada Stasiun I yaitu 5,11 ind $/ \mathrm{m}^{2}$. Kawasan ini berada jauh dari pemukiman warga sehingga minim akan aktivitas antropogenik yang terjadi sehingga tidak menggangu habitat 
makrozoobentos. Bahan organik pada stasiun ini yaitu $13,55 \%$ lebih tinggi dari Stasiun III namun lebih rendah dari Stasiun II. Sesuai dengan pernyataan [4] yang menyatakan bahwa kepadatan makrozoobentos sangat dipengaruhi oleh kondisi habitat dan tingginya aktivitas manusia pada habitat tersebut.

Tabel 4. Jenis makrozoobenthos pada setiap stasiun pengamatan

\begin{tabular}{|c|c|c|c|c|c|}
\hline No. & Filum & Kelas & Famili & Genus & Spesies \\
\hline 1 & Annelida & Polychaeta & Nepthyidae & Nephtys & Nephtys sp. \\
\hline 2 & Arthropoda & Malacostraca & Ocypodidae & Ocypode & $\begin{array}{l}\text { Ocypode } \\
\text { cordimanus }\end{array}$ \\
\hline 3 & & & Albunidae & Albunea & Albunea carabus \\
\hline 4 & & & Eulimidae & Eulima & Eulima inca \\
\hline 5 & & Gastropoda & Olividae & Olividae & Olividae stayelr \\
\hline 6 & Mollusca & & Turitellidae & Turitella & Turitella terebra \\
\hline 7 & & Rivalyia & Mesodematidae & Atactodea & Atactodea striata \\
\hline 8 & & Bivalvia & Donacidae & Donax & Donax faba \\
\hline 9 & Sipuncula & Sipunculidea & Sipunculidae & Sipunculus & Sipunculus sp. \\
\hline
\end{tabular}

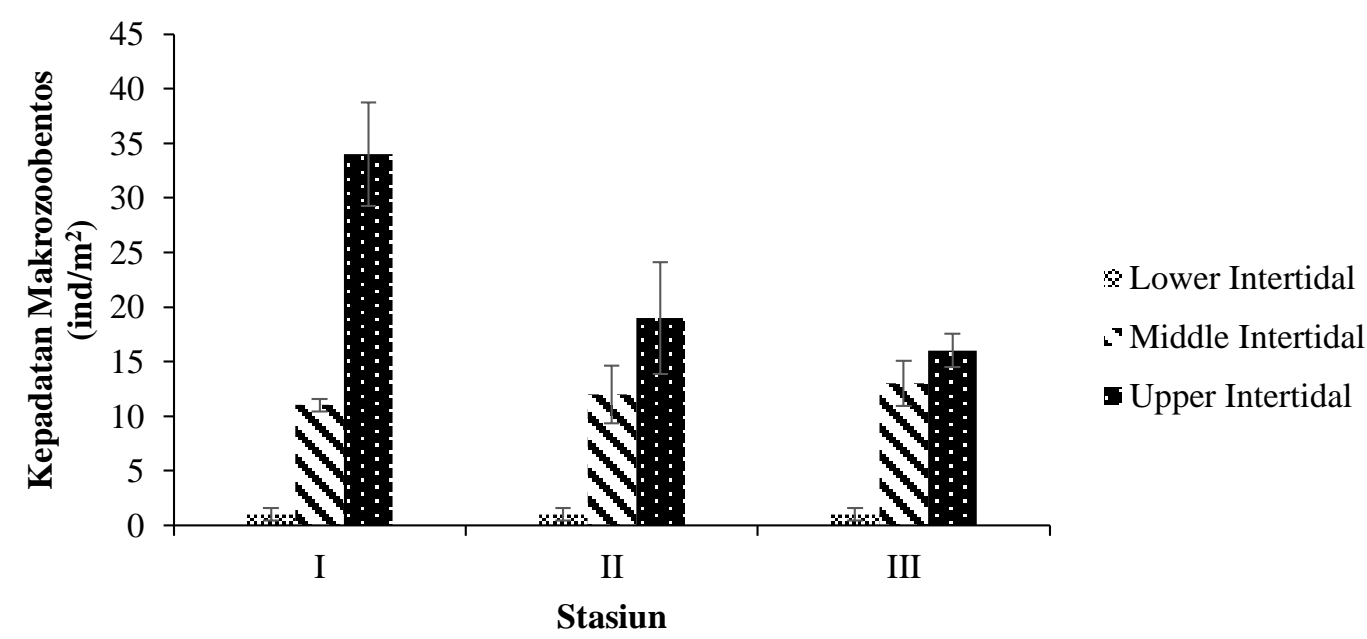

Gambar 2. Kepadatan makrozoobentos setiap zona intertidal pada setiap stasiun pengamatan

Kepadatan makrozoobentos pada Stasiun II yaitu $3,56 \mathrm{ind} / \mathrm{m}^{2}$, lebih rendah dibandingkan dengan Stasiun I. Stasiun ini merupakan kawasan wisata, dimana aktivitas manusia mempengaruhi kawasan tersebut sehingga habitat dari makrozoobentos terganggu. namun bahan organik pada stasiun ini yaitu $19,46 \%$ merupakan yang tertinggi dibandingkan dengan Stasiun I dan Stasiun II, ini disebabkan oleh dekatnya kawasan dengan perumahan masyarakat dan merupakan kawasan wisata. Walaupun bahan organik pada stasiun ini tinggi namun karena adanya aktivitas masyarakat menyebabkan adanya tekanan ekologis dan mempengaruhi kepadatan makrozoobentos. Sesuai dengan pernyataan [5] tinggi rendahnya nilai kepadatan didukung oleh persentase kandungan bahan organik di perairan. Hal ini di duga disebabkan bahan organik berperan penting dalam menyediakan sumber makanan bagi organisme gastropoda.

Kepadatan makrozoobentos pada Stasiun III yaitu $3,33 \mathrm{ind} / \mathrm{m}^{2}$ merupakan stasiun yang nilai kepadatannya terendah dibandingkan dengan Stasiun I dan Stasiun II. Pada kawasan ini dekat dengan muara sungai dan terpengaruh aktivitas manusia 
sehingga adanya pengaruh air tawar yang masuk dari daratan mempengaruhi habitat makrozoobentos. Hal ini sesuai dengan pendapat [6] kepadatan dan distribusi gastropoda dipengaruhi oleh lingkungan habitatnya, ketersediaan makanan, pemangsaan, dan juga kompetisi. Tekanan ekologis dan perubahan lingkungan seperti masuknya air tawar dari sungai mempengaruhi kepadatan makrozoobentos.

\section{Keanekaragaman, Dominansi dan Keseragaman Makrozoobentos}

Indeks keanekaragaman makrozoobentos pada zona intertidal di Desa Sambungo pada pengamatan ini berkisar antara 1,18 hingga 1,54 (Tabel 5). Stasiun I dengan nilai indeks keanekaragaman sebesar 1,18, Stasiun II dengan nilai indeks keanekaragaman sebesar 1,54 dan Stasiun III dengan nilai indeks keanekaragaman sebesar 1,19. Keanekaragaman tertinggi berada pada Stasiun II dan yang terendah berada pada Stasiun I.

Berdasarkan kriteria keanekaragaman pada Stasiun I, Stasiun II dan Stasiun III maka dapat disimpulkan bahwa kategori indeks keanekargaman pada semua stasiun masuk kategori sedang dimana nilai indeksnya berkisar antara $1,0 \leq \mathrm{H}^{\prime}<3,0$ : keanekaragaman sedang, penyebaran jumlah individu sedang dan kestabilan perairan telah tercemar sedang. Ekosistem dapat dikatakan normal, bila dicirikan oleh adanya keanekaragaman komunitas yang tinggi tanpa ada spesies yang dominan serta pembagian jumlah individu per spesies relatif merata.

Tabel 5. Keanekaragaman, Dominansi dan Keseragaman Makrozoobentos

\begin{tabular}{cccc}
\hline Stasiun & H' $^{\prime}$ & $\mathbf{C}$ & $\mathbf{E}$ \\
\hline I & 1,18 & 0,52 & 0,03 \\
II & 1,54 & 0,39 & 0,06 \\
III & 1,19 & 0,51 & 0,04 \\
\hline
\end{tabular}

Menurut [7], tinggi rendahnya nilai indeks keanekaragaman jenis dapat disebabkan oleh jumlah jenis atau individu yang didapat kondisi substrat, kondisi ekosistem di wilayah pesisir. Penjelasan ini mendukung hasil penelitian dengan adanya beberapa jenis yang ditemukan dalam jumlah yang lebih melimpah daripada jenis lainnya.

\section{Pola Sebaran}

Pola sebaran makrozoobentos di zona intertidal Desa Sambungo pada pengamatan ini berkisar antara 2,81 - 3,76 (Tabel 6). Stasiun I dengan nilai indeks morisita 3,05, Stasiun II dengan nilai indeks morisita sebesar 3,76 dan Stasiun III dengan nilai indeks morisita sebesar 2,81 .

Tabel 6. Pola Sebaran Makrozoobentos

\begin{tabular}{ccc}
\hline Stasiun & Id & Pola Sebaran \\
\hline I & 3,05 & Mengelompok \\
II & 3,76 & Mengelompok \\
III & 2,81 & Mengelompok \\
\hline
\end{tabular}

Berdasarkan kriteria indeks morisita pada Stasiun I, Stasiun II dan Stasiun III dengan nilai $\mathrm{Id}>1$ maka dapat disimpulkan bahwa penyebaran makrozoobentos pada zona intertidal Di Desa Sambungo ialah bersifat mengelompok Hal ini sesuai dengan pernyataan menurut [8] pola dengan sebaran mengelompok adalah pola organisme atau biota di suatu habitat yang hidup berkelompok dalam jumlah tertentu.

Pola penyebaran sangat khas pada setiap spesies dan jenis habitat. Penyebab terjadinya pola sebaran tersebut akibat dari adanya perbedaan respon terhadap habitat. Pola penyebaran mengelompok dengan tingkat pengelompokan yang bermacammacam merupakan bentuk penyebaran yang paling umum terjadi, karena individuindividu dalam populasi cenderung membentuk kelompok dalam berbagai ukuran. 


\section{KESIMPULAN DAN SARAN}

\section{Kesimpulan}

Berdasarkan hasil penelitian ini diperoleh kesimpulan mengenai struktur komunitas makrozoobentos yaitu diantaranya:

1. Makrozoobentos pada zona intertidal di Desa Sambungo terdiri dari, 4 Filum (Annelia, Arthopoda, Mollusca dan Sipuncula), 5 kelas (Polychaeta, Malacostraca, Gastropoda, Bivalvia dan Sipunculidea) dan 9 genus (Nephtys, Ocypode, Albunea, Eulima, Olividae, Turitella, Atactodea, Donax dan Sipunculus). Kepadatan makrozoobentos di zona intertidal Desa Sambungo tergolong rendah berkisar antara $3,33-5,11 \mathrm{ind} / \mathrm{m}^{2}$.

2. Keanekaragaman (H') makrozoobentos pada setiap stasiun dikatagorikan sedang. Indeks keseragaman (E) pada setiap stasiun dikatagorikan dalam keadaan tidak seimbang. Indeks dominansi (C) pada seluruh stasiun dikatagorikan dominansi sedang.

3. Pola distribusi makrozoobentos secara menyeluruh pada setiap stasiun bersifat teratur dan mengelompok

\section{Saran}

Mencermati hasil yang ada perlu kiranya dilakukan penelitian lanjutan mengenai faktor lainnya seperti zona, arus, pasang-surut, dan gas-gas terlarut yang di duga memiliki hubungan erat dengan komposisi sedimen dan struktur komunitas makrozoobentos di Desa Sambungo Kecamatan Silaut Kabupaten Pesisir Selatan Provinsi Sumatera Barat dengan metodologi lain yang lebih baik agar hasil dari analisis data lebih terukur.

\section{DAFTAR PUSTAKA}

1. Mucha, A.P., M.T.S.D. Vasconcelos and A.A. Nordalo. (2003). Macrobentic Community in the Douro Estuary Relation Eith Trace Metals and Natural Sediment Characteristic. Environment Pollution.

2. Odum, E.P. (1993). Dasar-dasar Ekologi. Diterjemahkan dari Fundamental of Ecology oleh T. Samingan. Gadjah Mada University Press. Yogyakarta

3. Brower J.E., and J. H. Zar. (1990). Field and Laboratory Methods for General Ecology. Brown Co Publisher. Iowa

4. Nurdin, J., M. Neti, A. Anjas, D. Rio, M. Jufri. (2006). Kepadatan populasi dan pertumbuhan kerang darah Anadara antiquata L (Bivalvia: Arcidae) di Teluk pisangpisang, Kota Padang, Sumatera Barat. Makara Sains, 10 (2) : 96 - 101.

5. Riniatsih, I. dan Widianingsih. (2007). Kelimpahan dan Pola Sebaran Kerang-Kerangan (Bivalve) di Ekosistem Padang Lamun, Perairan Jepara. Jurnal Ilmu Kelautan, 12(1): 53-58

6. Silaen, I.F., B. Hendrarto, dan M.N. Supardjo. (2013). Distribusi dan Kepadatan Gastropoda pada Hutan Mangrove. Journal of Management of Aquatic Resources, 2(3): 93-103.

7. Arbi, U.Y. (2012). Komunitas moluska di padang lamun pantai Wori, Sulawesi Utara. Bumi Lestari, 12 (1) : 55 - 65.

8. Werdiningsih, R. (2005). Struktur Komunitas Kepiting di Habitat Mangrove, Pantai Tanjung Pasir, Tangerang, Banten. Fakultas Matematika dan Ilmu Pengetahuan Alam. Institut Pertanian Bogor. Bogor. 